\title{
THE CLINICAL SIGNIFICANCE OF CALCIUM CONCENTRATION IN THE SERUM OF CHILDREN AND POSSIBLE ERRORS IN ITS DETERMINATION *
}

\author{
B. KRAMER, F. F. TISDALL AND J. HOWLAND \\ BALTIMORE
}

For the evaluation of calcium determinations on serum, plasma or whole blood it is necessary to know, first, whether the concentration of calcium is nearly constant and second, what factors influence this concentration. As the result of several thousand determinations in this laboratory, we believe that the calcium concentration of the serum of children is singularly constant and that the concentration is strikingly altered in only two conditions that we have met (a) tetany, (b) kidney insufficiency with or without nephritis.

In the last three years, several papers have appeared that would seem to show that the calcium concentration of the serum is not constant, that high values may be obtained even in frank tetany and that very low values may be found in the serum of children who present no evidences of tetany. This is entirely at variance with our experience. For this reason we wish to record some of our results in a variety of different diseases. We also wish to point out the more common factors that, in our experience, may lead to error in the determinations of small amounts of calcium.

The work of physiologists-Loeb, ${ }^{1}$ Keith-Lucas, ${ }^{2}$ Matthews, ${ }^{3}$ Mines and others-demonstrates the extreme susceptibility of the tissues, especially the nerves and muscles, to slight changes in the inorganic concentration of the tissue fluids. Especially has this been shown to be true of calcium. It would, therefore, a priori appear unlikely that marked changes in the concentration of the calcium would occur without manifest evidence of the change. An examination of available figures shows that on the whole the results of calcium determinations are remarkably constant not only for the same animal but for animals of different species. Not many series by the same experimenters are available. With cows, Meigs, Blatherwick and

* Received for publication July 1, 1921.

* From the Department of Pediatrics, The Johns Hopkins University.

1. Loeb, J.: Beitr. z. Physiol. Festschrift für Adolf Fick, 1899. Loeb, J. and Ewald, W. F.: J. Biol. Chem. 25:377, 1916.

2. Keith-Lucas: J, Physiol, 37:459, 1908.

3. Matthews, A. P.: Am. J. Physiol. 11:455; 1904.

4. Mines, G. R.: J. Physiol. 37:408, 1908. 
Cary ${ }^{5}$ found a marked constancy. Thirty of their determinations give an average calcium concentration of $10.2 \mathrm{mg}$. per hundred c.c. of plasma. The highest figure was 11.2, the lowest 9.1. We have found the average for the $\operatorname{dog} 11.1$, for the sheep 10.2, for the rat 9.5. With normal adults we have found the concentration to be from 9 to $10.5 \mathrm{mg}$. and with normal children from 10 to $11 \mathrm{mg}$. per hundred c.c. serum.

\section{Calcium Concentration of Serum in Health and Disease Expressed as MG. PER $100 \mathrm{cC}$.}

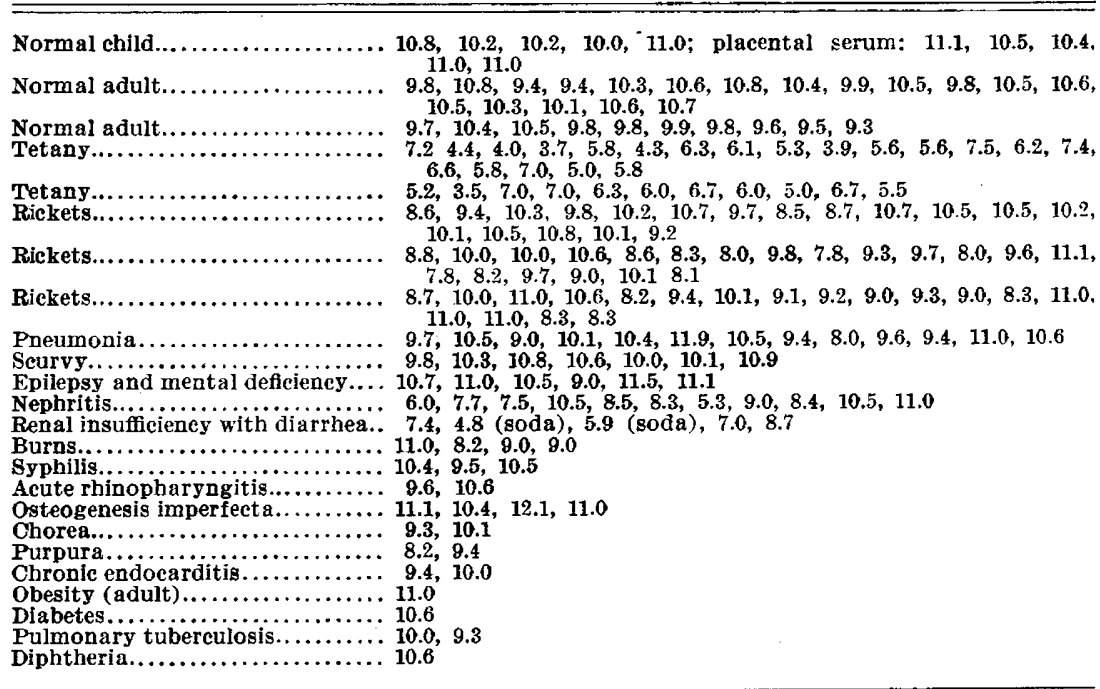

The accompanying table contains the results of a number of calcium determinations made in this laboratory on the serum of normal adults, normal children and children suffering from various diseases. The children with rickets or tetany were all under three years of age, some of the others were older. As previously stated, the concentration of calcium in the serum of normal adults is usually lower than that of normal children. Physiological conditions such as diet, exercise, etc., seem to exert little if any influence on the calcium of the serum.

In a series of thirty-one cases of active tetany the calcium concentration in the serum varied from 3.7 to $7.4 \mathrm{mg}$. per hundred c.c. serum, the average being $5.8 \mathrm{mg}$. Fifty-six cases of rickets showed an average concentration of serum calcium of $8.6 \mathrm{mg}$. per hundred c.c. The lowest value found was 8.0 while the highest was $11.1 \mathrm{mg}$. For reasons that we have considered fully elsewhere, we believe that the low concentration of calcium not infrequently found

5. Meigs, E. B., Blatherwick, N. R., and Cary, C. A.: J. Biol. Chem. 37:1, 1919. 
with rickets depends not on the rickets per se. but on an associated latent tetany.

In nephritis or in renal insufficiency not associated with nephritis (polycystic kidney, burns, dehydration with severe diarrhea, etc.) the concentration of calcium was low in twelve out of twenty cases. Some of these values, especially when infants had been treated with soda, are comparable to the values found in active infantile tetany. In several of the children treated with soda symptoms of tetany developed. In no other of the clinical conditions studied did we find any significant change in the concentration of calcium in the serum.

Our figures do not confirm those published by Denis and Talbot. ${ }^{\circ}$ These authors found a very low calcium content of the serum with respiratory infections, especially pneumonia, but on the other hand they found exceedingly high figures with the same infections. Thus, in pneumonia their variation was from 12.1 to less than $2 \mathrm{mg}$. per hundred c.c. In a series of thirteen cases of pneumonia, three of which were fatal, we found essentially normal figures in all instances but one. This one child, suffering from rickets, had a calcium content of 8.0. From our own experience with calcium determinations in pneumonia and other diseases it is impossible for us to understand the figures published by Denis and Talbot. With diseases such as epilepsy, chorea, mental deficiency and mild nutritional disorders which we have never found associated with any calcium disturbance, they report variations from 1.0 to $13.5 \mathrm{mg}$. per hundred c.c.

Nor do our findings confirm those of Hess and Killian ${ }^{7}$ in regard to infantile scurvy. These authors reported calcium determinations on the plasma of seven children with scurvy, the concentration in all cases being low, from 3.4 to $7.2 \mathrm{mg}$. Later Hess states that subsequent determinations "have generally yielded normal results." We have had a series of seven cases of scurvy, all in the active stage. The results have been normal with every determination (9.8-10.9, average 10.3 ).

We are quite unable to understand the findings of Brown, MacLachlan and Simpson, ${ }^{8}$ who state that they found an average of 9.5 mg. calcium per hundred c.c. of whole blood in normal infants. This figure is only 10 per cent. less than the average for the serum of normal infants. If these figures are correct, one would have to assume practically the same concentration of calcium in the corpuscles and in the serum. We have consistently failed to find any calcium in normal human corpuscles and even those who assert that calcium may be present in the corpuscles recognize that the amount is very small.

6. Denis, W., and Talbot, F. B.: Am. J. Dis. Child. 21:29 (Jan.) 1921.

7. Hess, A. F., and Killian, J. A.: Proc. Soc. Exper. Biol. \& Med., 16:43, 1918.

8. Brown, A., MacLachlan, I. F., and Simpson, R.: Am. J. Dis. Child. 19:413 (May) 1920. 
Stheeman ${ }^{\theta}$ in the course of a study of the electrical excitability of the nerves of children found no consistent relationship between the concentration of the calcium in the serum and the irritability of the nerves. Our experience has taught us that there is a very definite relationship.

We feel that it is proper, since our results have been very con. sistent for a number of years, with a great many determinations, to call attention to the sources of error that may be encountered in determining calcium with small quantities of plasma, serum or blood. With all micro methods the permissible error is greater than with methods in which large amounts of material are used. It is only through extreme care that errors are avoided in micro methods. Only reagents that have been proven to be free from calcium should be employed. Nitric acid, which is used in the method of wet ashing of blood, may, at times, contain calcium in measurable amounts. Trichloracetic acid, a frequently used deproteinizing agent, may likewise contain calcium. Even distilled water may contain traces of calcium. It is, therefore, advisable to use as few reagents as possible. Lyman ${ }^{10}$ called attention to the presence of calcium in filter paper. When trichloracetic acid is used for the removal of protein from serum or whole blood and the coagulum separated by filtration through a high grade acid-washed filter paper, we have found that the filtrate may remove from the filter paper a quantity of calcium sufficient to give an error of 75 per cent. in the determination of this element. Thro and Ehn ${ }^{11}$ have had a similar experience. Since it is impossible to tell what samples of filter paper contain calcium we have dispensed with filtrations in all calcium determinations in serum and whole blood.

While the presence of calcium as a contamination may account for occasional high results, the low figures more frequently found, require a different explanation. Kohlrausch ${ }^{12}$ and Richards and his collaborators ${ }^{13}$ have found that calcium oxalate is not wholly insoluble in water, so that if the precipitate is washed a loss of calcium may occur. This may be reduced to a minimum by washing in such a way that the precipitate is in contact with a dilute solution of ammonium oxalate until the last stage of the washing. We have controlled our own determinations by using a method in which washing is not required.

The precipitation of calcium as the oxalate from serum directly or from solutions of serum ash or serum which has been freed of its

9. Stheeman, H. A.: Jahrb. f. Kinderh. 94: 1921.

10. Lyman, H. : J. Biol. Chem. 29:169, 1917.

11. Thro, W. C., and Ehn, N.: Proc. Soc. Exper. Biol. \& Med. 18:189, 1921.

12. Kohlrausch: Quoted from Seidell-Solubilities of Inorganic and Organic Compounds, Ed. 2, D. Van Nostrand Co, New York, p. 209.

13. Richards, T. W., McCaffrey, C. F., and Bisbee, H.: Proc. Acad. of Arts and Sciences 36:375, 1901 . 
protein must be accomplished in the presence of both magnesium and phosphates. When solutions of serum ash are rendered alkaline with ammonia a fluffy precipitate of calcium phosphate forms. This must be completely redissolved before the addition of the oxalate. The concentration of either magnesium or phosphate in unashed serum or plasma is small, except in certain pathological conditions. ${ }^{14}$ Richards and his collaborators have determined the conditions under which a quantitative separation of calcium from magnesium may be accomplished. The concentration of magnesium in serum and plasma is so small that it cannot be considered a serious source of error.

McCrudden ${ }^{15}$ showed that unless the solution from which calcium is precipitated is sufficiently acid, the calcium will be precipitated in part as the phosphate. If a precipitation of calcium phosphate occurs titration with permanganate will yield low results. We have found the optimum $p_{\mathrm{H}}$ of the fluid for the quantitative precipitation of calcium as the oxalate to be from 5.2 to 6.2 . As the alkalinity increases the amount of calcium that is precipitated as the phosphate also increases. The error in determination thus caused may be very large. The addition of sodium citrate to blood increases the alkalinity of the plasma and may result in the precipitation of part of the calcium as the phosphate. Plass ${ }^{16}$ states that this may be avoided by using sodium citrate that has been neutralized to litmus by the addition of citric acid. The amount of fluid in which precipitation is accomplished and the length of time allowed for precipitation are also important factors.

The use of hydrochloric acid in an analysis in which the final determination is a permanganate titration should be avoided since hydrochloric acid is oxidized by permanganate to chlorine. According to the method used this may yield high or low results. With reasonable care there is no difficulty with permanganate titration in reading the end point.

\section{CONCLUSIONS}

A large number of calcium determinations on the serum of normal children shows a marked constancy in the concentration of this element.

In only two conditions commonly met with, tetany and renal insufficiency, is the concentration of calcium markedly reduced. In no condition has it been found increased above normal limits.

There are many possibilities of error in methods for the determination of small amounts of calcium. Some of the more common of these are discussed.

14. Marriott, W. McK., and Howland, J.: Arch. Int. Med. 18:708 (Nov.) 1916.

15. McCrudden, F. H.: J. Biol. Chem. 7:83, 1909.

16. Personal communication. 